\title{
TAX REFORMS FOR THE DEVELOPMENT OF FISCAL SPACE
}

\author{
Inna Lunina', Olena Bilousova², Nataliya Frolova ${ }^{3}$
}

\begin{abstract}
A reduction of the tax burden on corporate income in order to stimulate drivers of economic development has become the important issue of tax reform in many countries in recent decades. Tax competition forces national governments to take well-balanced solution on increasing outward and domestic investments as well as ensuring the fiscal capacity of the budget to cope with urgent socio-economic problems under enhancing fiscal risks. The purpose of the article is to assess the impact of tax reforms, addressing reducing the corporate income tax burden, on the fiscal space and investment processes in the EU countries and Ukraine, to establish directions of improvement of the tax system in Ukraine and other transition economies in order to spur the expansion of fiscal space. The research subject covers tax policy settings that shape fiscal space development. Research methodology. In accordance with the purpose of the article, the research methods are set as follows: abstract-logical; systemic analysis; analysis and synthesis; graphical method. Findings. By summing up theoretical ideas on the issue of feasibility of cutting corporate income tax, we have arrived at the conclusion that this measure has a significant impact on the improvement of tax competitiveness of the national economy. The gain from its application is confirmed by the best practices of many European countries.

The results of the tax reform in Ukraine have proved that a traditional approach to the choice of tax issues in contrast with developed economies - do not comply with theoretical provisions on increasing the competitiveness of the national economy and fostering investments. This is conditional on the specific tax effects in Ukraine due to the restriction of the key economic freedoms (investment, financial, property rights protection and judicial effectiveness) needed for successful entrepreneurship, as well as of a high rate of corruption, which increases the costs of business activity. Such effects include, in particular, a drop of tax revenues in the short and long term while reducing the level of corporate income taxation; a high level of tax evasion, capital outflow instead of expanding investment in the national economy.

It is argued that the emphasis while carrying out tax reforms and expanding fiscal space in transition economies considering the specific effects of changing corporate income tax provisions, should be made on ensuring the long-term sustainability of public finances through measures of budget adjustments aimed at avoidance shifting the existing fiscal problems on future generations; harmonization of national tax legislation with the EU regulations and prevention of tax evasion; increasing the financial capacity of enterprises by introducing targeted innovation tax incentives, which will gain higher competitiveness of the country in the world markets and as a result facilitate the growth of the country's future revenue receipts.
\end{abstract}

Key words: tax reform, tax burden, investment rate, fiscal space, corruption, shadow economy, targeted innovation tax incentives.

JEL Classification: E22, H2O, O23

\footnotetext{
Corresponding author:

${ }^{1}$ State Organization "Institute for Economics and Forecasting of the National Academy of Sciences of Ukraine", Ukraine.

E-mail: ilunina@ukr.net

ORCID: http://orcid.org/0000-0003-3812-4802

ResearcherID: AAP-2680-2020

${ }^{2}$ State Organization "Institute for Economics and Forecasting of the National Academy of Sciences of Ukraine", Ukraine.

E-mail: Bilousova.os@gmail.com

ORCID: https://orcid.org/0000-0001-7434-3469

ResearcherID: AAB-1694-2019

${ }^{3}$ State Organization "Institute for Economics and Forecasting of the National Academy of Sciences of Ukraine", Ukraine.

E-mail: nata.frolova99@gmail.com

ORCID: https://orcid.org/0000-0002-7979-950X
} 


\section{Introduction}

A reduction of the tax burden on corporate income, in particular by reducing the corporate income tax rate has become the important issue of tax reform in Ukraine, as well as in many countries in Europe and worldwide in recent decades.

The top corporate tax rate in the EU countries (EU-28) in 2018, according to Eurostat, averaged at $21.9 \%$ compared with $23.8 \%$ in 2009 and $33.5 \%$ in 1999 . Employers' compulsory social security contributions in the EU countries decreased from $24.8 \%$ to $22.2 \%$ on average for the period 2009-2018 (Employer social security tax rates, 2019). At the same time, tax ratio in the EU countries increased from $37.7 \%$ GDP on average during $2004-2008$ to $37.8 \%$ GDP in $2009-2013$ and peaked $38.7 \%$ GDP in 2014-2017.

In Ukraine, the corporate income tax rate decreased from $30 \%$ in 1999 to $21 \%$ in 2009 and then in 2014 it dropped to 18\%. Employers' compulsory social security contributions fell down to $22 \%$ in 2016 . The total tax ratio (including all taxes and compulsory social security contributions) averaged $34.0 \%$ GDP for the period 2014-2018 compared with $35.4 \%$ in 2009 2013 and $35.7 \%$ in $2005-2008$. Thus, the total tax ratio and the corporate income tax rate in Ukraine in recent years have been both much lower in comparison with many other European countries. However, a significant reduction of tax and contribution rates has promoted neither the improvement of the Ukrainian tax competitiveness nor its investment boom. This suggests that there are other specific effects which should be looked at.

The problems of tax reform efficiency and its impact on economic growth have been scrutinized by international experts, including E. Asen, J. Arnold, A.L. Bovenberg, B. Brys, D. Bunn, V.H. Dehejia, Ph. Genshel, A. Johansson, C. Heady, R.H. Gordon, S. Matthews, J. Owens, A. Smith, V. Tanzi, M. Porter, Ch. B. Blankart, M. Overesch, J. Rincke, L. Vartia and others. Although, despite the continued attention of researchers and experts to these problems, follow-up studies are required to examine impact of tax reform on fiscal space development and investment in transition economies as well as in countries with different levels of economic freedom.

The purpose of the article is to assess effects (impact) of tax reforms, addressing reducing corporate income tax burden, on the development of fiscal space and investment processes in the EU countries and Ukraine, to justify ways of improvement of tax system in Ukraine. To accomplish this purpose, the following steps need to be taken: to provide a summary of theoretical ideas on the issue of reducing corporate income tax rates; to detect drivers that affect level of corporate income taxation; to discuss international practices towards better investment environment; to work out ways of improvement of the tax system of Ukraine in order to ensure fiscal space development.

The research subject covers tax policy settings that shape fiscal space development in transition economies.

Research methodology. In accordance with the purpose set, the research methodology is based on the following methods: abstract-logical method is applied to provide a summary of academic ideas on the issue of reducing corporate income tax rates; systemic analysis is applied to describe tax reforms; analysis and synthesis are used to assess the impact of tax changes on investment, tax revenues, public debt developments; graphical method is used to display cross-country comparisons and to illustrate the final conclusions of the article.

The novelty of the study comprises an application of a new approach of tax reform efficiency evaluation within a concept of sustainable development; identification of the determinants of specific tax effects that are attributed to the transition economies; a design of new ways of tax system improvement in such countries to support fiscal space development.

\section{Theoretical ideas on the issue of reducing corporate income tax rates}

The reduction of statutory corporate income tax rates plays an important role for potential investors, as it serves as a signal for them that the government of a country is carrying out a policy of investment facilitation. At the same time, the combination of low tax rates and broad tax base eliminates distortions with respect to the economic decisions of economic agents. In addition, it implies better tax administration (Brys, Matthews \& Owens, 2011). Such measures in the EU countries not only foster investment growth, but also result in higher tax revenues.

Reduction of tax rates, which contributes to capital investment growth, challenges the expansion of capital intensive activities. Even Adam Smith noted that "Capital cultivates land, capital employs labor. Tax that causes the outflow of capital... thus causes loss of all sources of income for society and its government. Capital outflow... brings not only to the lower capital return, but also inevitably cuts down ground rent and wages" (Smith, 1935).

Overall, reduction of tax rates on different stages of national economic development is an implicitly important driver of capital accumulation and capital investment increase, and therefore gives rise to economic growth. The findings of many studies - as noted by V. Tanzi - evidence that differences in per capita income and economic growth rates are mainly conditional upon the differences in capital accumulation (Tanzi, 2014).

High taxes and information asymmetry caused by international differences in capital taxation set up the most rigorous "obstacles" for foreign investors to enter the domestic market (Gordon \& Bovenberg, 1994; 
Porter, 2007). According to the famous US economist A. Harberger, under conditions of high capital mobility, the supply elasticity of this factor of production is in inverse proportion to the level of its tax burden, in other words, the higher the level of capital tax rates in a country, the lower the investment inflow in its economy (Blankart, 2000).

In conditions of high capital mobility, companies seek to choose countries where they can maximize their after-tax profit. Increasing of capital mobility while getting access to international markets also further stronger economic performance and growth of national economy (Kazutoshi, Hikaru \& Toshiki, 2018). Therefore, reduction of tax burden on corporate income, in particular by cutting corporate income tax rates, is one of the most influential condition for creation of competitive tax system (Bunn \& Asen, 2019).

Above mentioned theoretical provisions support there are the findings of some empirical studies, which suggest that cutting corporate income tax rates have the greatest impact on economic growth and facilitate country's investment environment (Johansson, Heady, Arnold, Brys \& Vartia, 2008).

In many countries, the reduction of corporate income tax rates has been accompanied by either increase of the tax receipts, or by keeping of the tax receipts at the same stable level, or by a minor reduction in tax receipts compared with a reduction in the tax rate due to the measures of the tax base expansion.

Fight for mobile factors of production and investments, forces the governments of neighboring countries (with higher tax ratio) to reduce their tax rates, in other words it stimulates processes of tax competition. According to some proxy estimates, in 2006 without tax competition in Western Europe the average corporate tax rate would have been 12.5 percentage points higher than actual rate (Overesch \& Rincke, 2011). A number of authors have even suggested that with perfect tax competition, the tax rate on capital must have fallen to $0 \%$ (Dehejia \& Genshel, 1998). In tax theory, such a policy is called a "race to the bottom".

One of the positive outcomes of tax competition is a higher after tax corporate profit, which, consequently, contributes to better corporate financial capacity in terms of capital and investment accumulation as essential drivers of economic growth (Kazutoshi, Hikaru \& Toshiki, 2018). For example, in recent German studies, the feasibility of cutting corporate tax rate from $30 \%$ to $25 \%$ has been based upon some findings by the Institute's IFO that it would add extra $14 \%$ of investments to the corporates. Furthermore, the reported profit would increase by about $4 \%$ due to the decline in tax evasion (Fuest, 2019).

With regard to negative consequences of tax competition, it caused tax base erosion due to the outflow of capital and labor resources to neighboring countries with less tax burden. Various experts point out that the geographical neighborhood of countries significantly increases the impact of tax competition on the reduction of tax rates (Braid, 1993).

During the preparation for the EU enlargement a significant discrepancy between corporate income tax rates appeared. Moreover, there was a consistent tendency of capital outflow to the transition economies, which became new EU members in 2004. Reduction of corporate income tax rates in the post-socialist EU

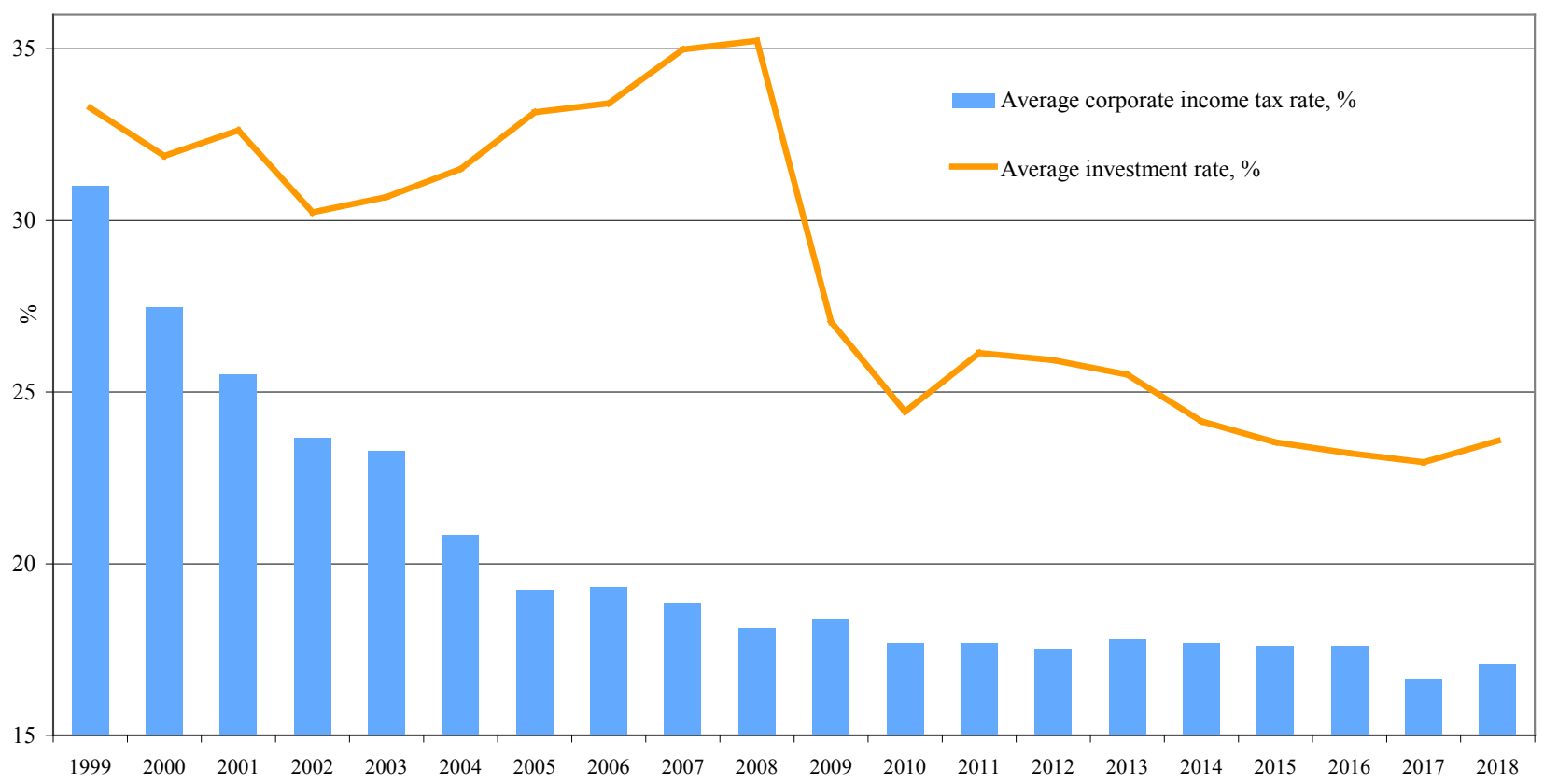

Figure 1. Corporate income tax rate, investment rate in the post-socialist EU countries in 1999-2018, \%

Source: Created by the authors according to the data from the Statistical Office of the European Union 


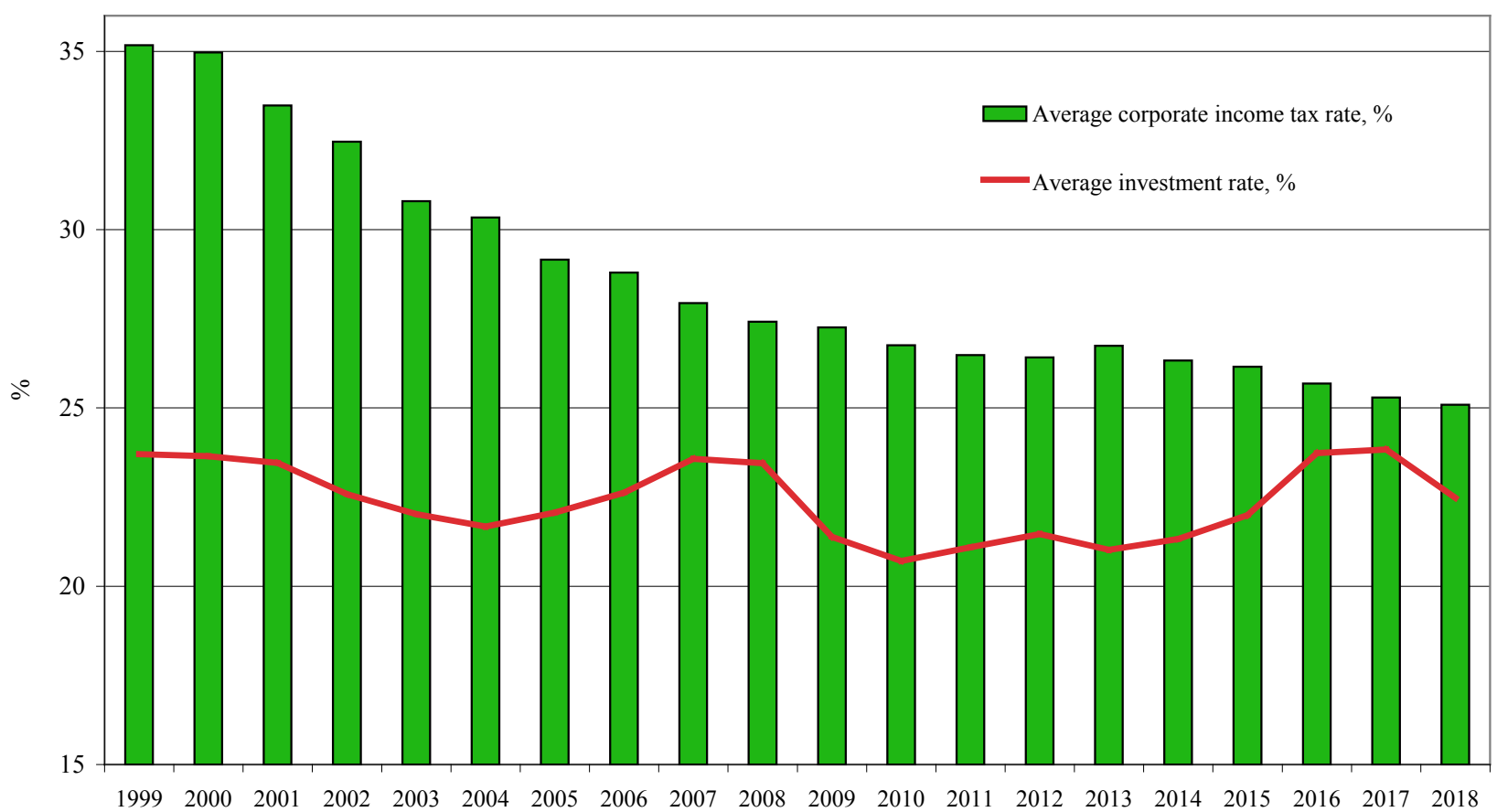

Figure 2. Corporate income tax rate, investment rate in the EU developed countries in 1999-2018, \%

Source: Created by the authors according to the data from the Statistical Office of the European Union

countries in the period 2002-2008 (on average from $23.65 \%$ to $18.12 \%$ ) accompanied by rising investment rate from $30.2 \%$ to $35.2 \%$ (Figure 1 ).

Despite cutting of corporate income tax rates in the developed EU countries, they were still at a higher level, and the average investment rate decreased from 23.5$23.7 \%$ in the period $1999-2001$ to $22.03 \%$ in 2003 and $21.7 \%$ in 2004 (Figure 2). In response to this situation policy makers from the EU, OECD and UN put all their efforts to launch anti-tax competition measures through a policy of tax harmonization (Remeur, 2015; Coughlan, 2015; European Commission, 2016).

Tax competition faced by many countries couples with the problem of tax exporting. This phenomenon occurs when residents of one country, if they work or own property in the other country, have to pay higher taxes there. In such circumstances, the government of the resident country may decide that it is inappropriate to reduce domestic tax rates, given that they are not as high as in the neighboring country (Braid, 2005). Tax exporting has the opposite effect on the level of tax rates compared with tax competition, i.e., tax rates remain at the previous level, although in some cases tax exporting might even result in tax rate increase.

Doubtless, in addition to tax rates and other tax law implications, tax ratio is also dependent on a number of non-tax factors, such as inflation (Rozen, 1992). As $H$. Rosen states, high inflation affects the real value of deductions from taxable income, which are settled in nominal terms. It does not only makes capital more vulnerable to inflation, but also distorts the efficiency of tax policy measures designed to reduce the tax burden on this factor of production.

V.Tanzi also draws attention to the fact that the attractiveness of a country for investments depends not only on tax rates but on different conditions (Tanzi, 2007), such as tax law transparency; certainty and predictability of tax changes; amount of costs related to tax administration and tax compliance; allocation of tax revenues, which implies services consumed by individuals and businesses in exchange for taxes paid; the state of public finance (budget deficit and public debt), which in case it worsens might lead to higher taxes in future; investment climate and legal framework of a country (rule of law) etc.

Thus, the key message of summing up theoretical ideas on the issue of feasibility of cutting corporate income tax is that it stimulates investments and accelerates growth of national economies. Best practices of many developed countries proved it to be a quite efficient measure. Nevertheless, in conditions of high capital mobility, there are other important determinants which make a divergent impact on the level of tax rates and tax burden on corporate income such as tax competition, tax exporting, inflation, tax law provisions and processes of its harmonization.

\section{The situation in Ukraine}

The development of Ukraine's tax system in recent decades has complied with the traditional approach of ensuring its tax competitiveness by reducing the tax 
burden on corporate income. The uniform statutory rate of corporate income tax was gradually cut down from $30 \%$ in $1999-2003$ to $25 \%$ in $2004-2010$, then to $23 \%$ in 2011 , to $21 \%$ in 2012 , to $19 \%$ in 2013 (it was reduced to 5\% for IT companies) and finally in 2014 it fell to its current level of $18 \%$.

Employers' compulsory social security contributions in Ukraine had a profound impact on the tax burden on corporates. However, since 2016 the contribution rates have been reduced to $22 \%$ compared with $36.76-49.7 \%$ before (depending on the occupational hazard class).

The nominal and relative reduction of the tax burden on corporate income of the Ukrainian enterprises (by reducing the rates of the unified employers' compulsory social security contributions and corporate income tax) was stipulated, on the one hand, to supply enterprises with additional financial resources that could potentially be invested in fixed capital and business development. On the other hand, it could eliminate shadow economy and, as a result, raise more budget revenues.

However, the tax cut did not have a significant positive effect on corporate investments. In Ukraine, the investment rate of nonfinancial corporations in the period of 2001-2003 (at this time corporate income tax rate was $30 \%$ ) averaged at $26.01 \%$ (calculated by authors on the basis of Eurostat methodology). In the period 2014-2018 (when corporate income tax rate was reduced to $18 \%$ ), average investment rate decreased to
$22.67 \%$. Whereas, growth of the investment rate of nonfinancial corporations in Ukraine in the period 20062008 to $33.5-36.6 \%$ and in 2012 to $30.7 \%$ was mainly determined by increase of capital transfers to enterprises from the state and local budgets of Ukraine (Figure 3).

The inflow of foreign investments in Ukraine in the period of 1999-2013 (according to the State Statistics Committee of Ukraine in different years it amounted to $0.3-1.1 \%$ GDP) international experts attribute mainly to the influence of non-tax factors, such as the privatization of state enterprises, availability of natural resources, low production costs (World Investment Report, 2013). Alongside this, the quality of local infrastructure, qualification of labor resources as well as other factors implying production efficiency and distinguishing characteristics of enterprises are also of a prior importance for the investors.

It should also be noted that the additional financial resources received by the Ukrainian enterprises did not result in higher investments in the national economy but were transferred abroad. In 2014-2018, the reduction of corporate income tax rate and the unified social contribution rate was followed by the rise of capital outflows from Ukraine (Figure 4).

Meanwhile, in the period of 2009-2013, foreign direct investments from Ukraine averaged at $4.4 \%$ GDP, in the period of 2014-2018 its annual volume grew by $70 \%$ and reached the level of $7.4 \%$ GDP.

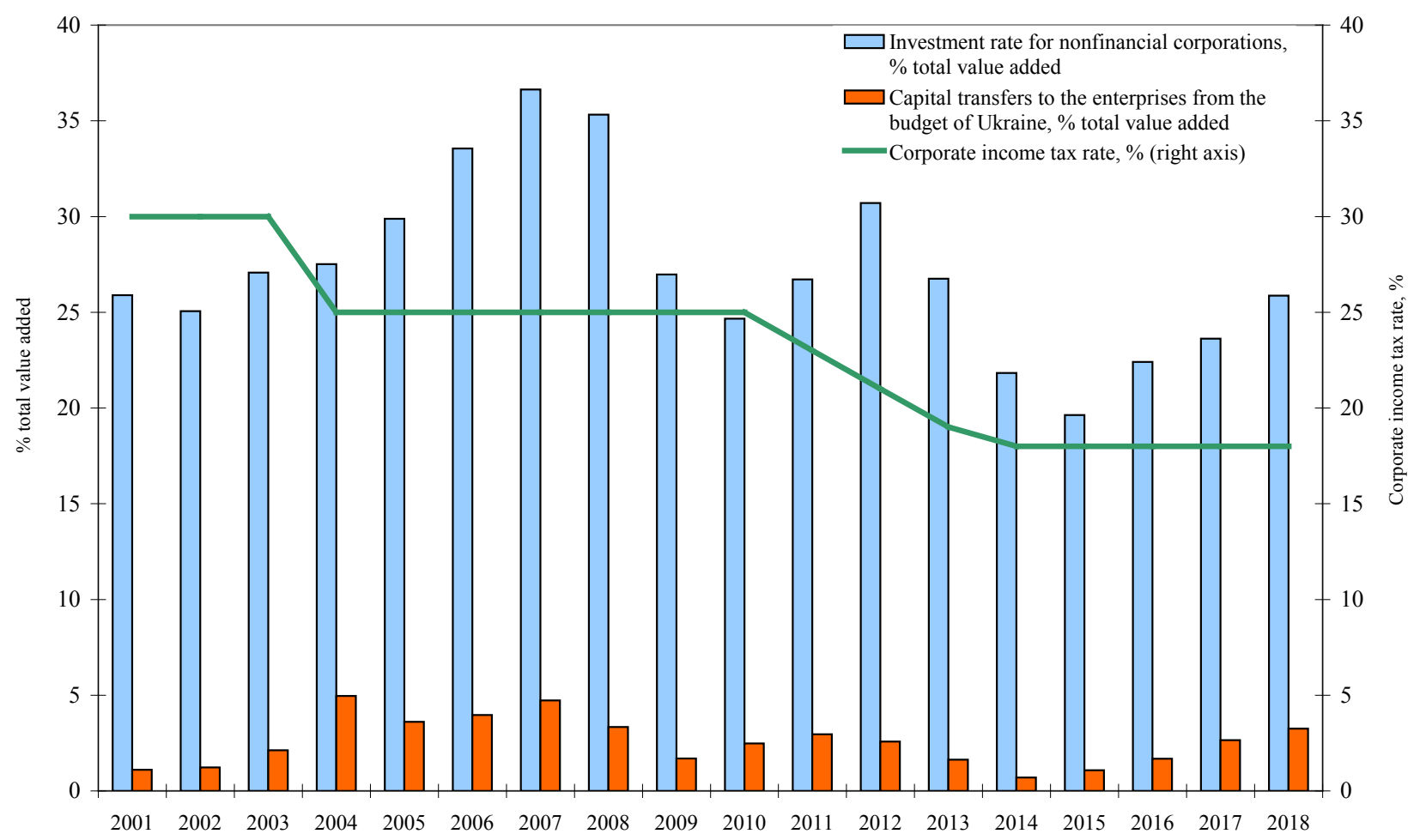

Figure 3. Dynamics of investment rate of nonfinancial corporations and capital transfers to the enterprises from the budget of Ukraine in 2001-2018, \%

Source: State Statistics Service of Ukraine; authors' calculation based on the data from the Ministry of Finance of Ukraine 


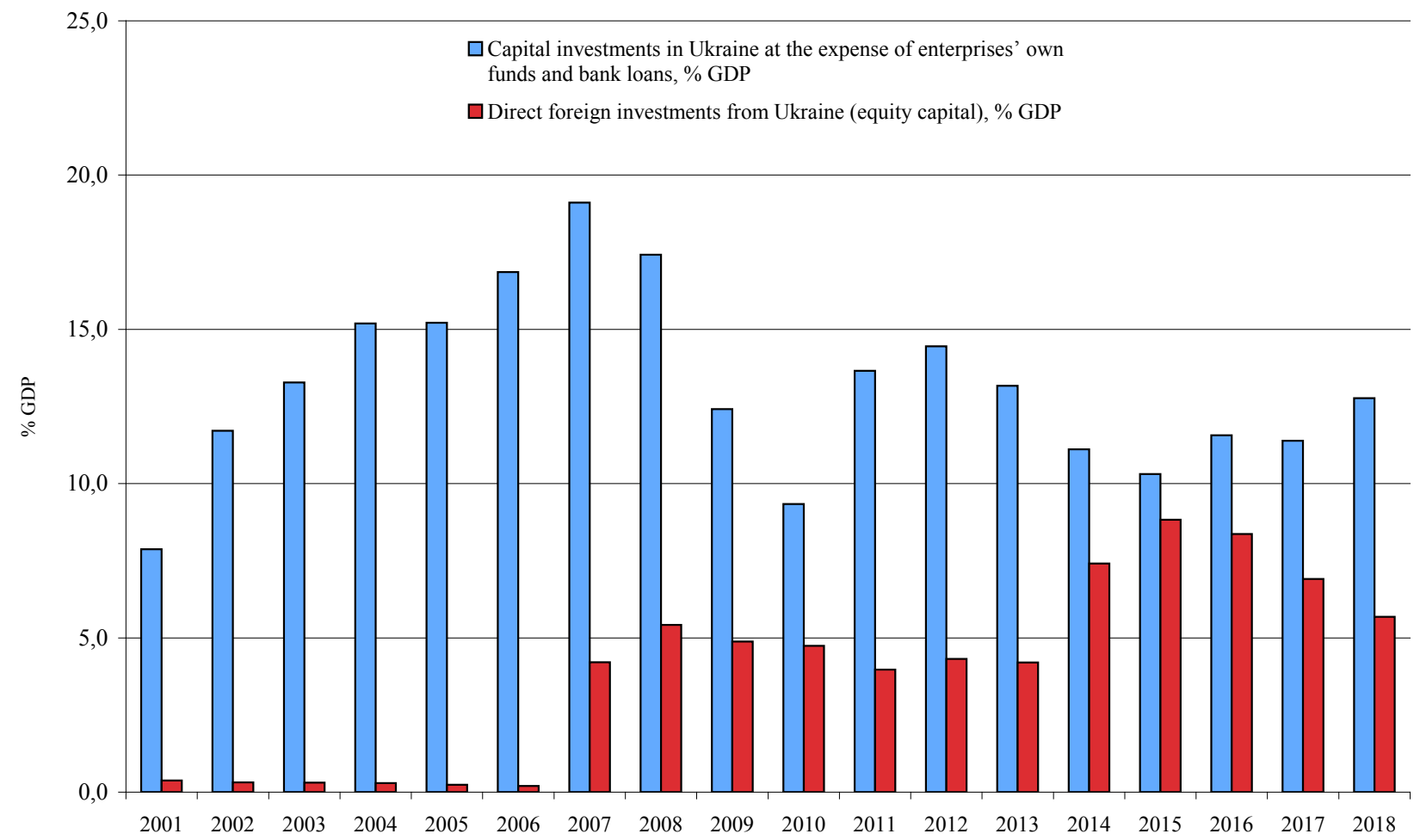

Figure 4. Capital investments in Ukraine and beyond its borders in 2001-2018, \% GDP

Source: National Bank of Ukraine; authors' calculations based on the data from the State Statistics Service of Ukraine

In addition, the reduction of tax burden on enterprises has not significantly improved the situation with shadow economy in Ukraine. During the period of 2008-2018 the size of shadow economy varied from 30 to $43 \%$ in terms of official GDP (according to the estimates of the Ministry for Development of Economy, Trade and Agriculture of Ukraine) (General trends of shadow economy in Ukraine, 2018 ), which exceeded the highest level in the OECD countries. For instance, in the period of 2014-2018, this excess varied from 9.2 to $19.7 \%$ (see Table 1 ).

In the period of 2004-2018, there were processes of deterioration of the state of public finances in Ukraine:

1. Fast growth of public debt. The total amount of direct and state-guaranteed public debt has increased from $24.75 \%$ GDP in 2004 to $38.4 \%$ in 2013 , then to $80.9 \%$ in 2016 and finally to $60.9 \%$ GDP at the end of 2018.

2. A considerable share of borrowed funds was assigned to finance current government spending. During this period less than a quarter of direct government debt gains was spent on investment, lack of which neglected necessary preconditions for economic growth and reduction of the tax burden on corporate income. Whereas, the annual volume of budget investments in Ukraine in the period of 2004-2018 on the average was only $1.82 \%$ GDP (it varied within $0.9-2.8 \%$ GDP). Based on this indicator, Ukraine ranked last among the
Table 1

Size of shadow economy in Ukraine and OECD countries, \% official GDP

\begin{tabular}{|c|c|c|c|c|}
\hline Years & Ukraine & $\begin{array}{c}\text { OECD, } \\
\text { weighted } \\
\text { average }\end{array}$ & $\begin{array}{c}\text { OECD, } \\
\text { highest }\end{array}$ & $\begin{array}{c}\text { OECD, } \\
\text { minimum }\end{array}$ \\
\hline 2008 & 34.0 & 13.2 & 24.3 & 7.0 \\
\hline 2009 & 39.0 & 13.8 & 25.0 & 7.6 \\
\hline 2010 & 38.0 & 13.5 & 25.4 & 7.2 \\
\hline 2011 & 32.0 & 13.2 & 24.3 & 7.0 \\
\hline 2012 & 32.0 & 13.0 & 24.0 & 7.0 \\
\hline 2013 & 35.0 & 12.5 & 23.6 & 6.6 \\
\hline 2014 & 43.0 & 12.4 & 23.3 & 6.3 \\
\hline 2015 & 40.0 & 12.2 & 22.4 & 5.9 \\
\hline 2016 & 35.0 & 11.9 & 22.0 & 5.6 \\
\hline 2017 & 32.0 & 11.6 & 21.5 & 5.4 \\
\hline 2018 & 30.0 & 11.2 & 20.8 & 5.1 \\
\hline
\end{tabular}

Source: Ukraine - the Ministry for Development of Economy, Trade and Agriculture of Ukraine; OECD countries - authors' calculations based on the data from Schneider F., Boockmann B. Die Größe der Schattenwirtschaft - Methodik und Berechnungen für das Jahr 2020. Linz und Tübingen, 4. Februar 2020. S. 25.

post-socialist countries of Europe, which negatively affected the country's competitive advantage.

3. High cost of the Ukrainian government borrowings has led to the increase of public expenditures on debt servicing. In the period of 2004-2018, this increase outran the growth of public debt. Direct public debt has increased 27 times, meanwhile, the cost of public debt 
servicing has grown in 36 times (from 3.2 billion UAH in 2004 to 116.1 billion UAH in 2018).

4. Constraints on budget financing of social sphere. In the period of 2015-2018, expenditures on public debt servicing exceeded budget expenditures on health care. It should be noted that in Ukraine, annual public expenditures on health care in 2004-2018 averaged at $3.62 \%$ of GDP which constituted only $52 \%$ of such expenditures in the EU (at the average level of $7.0 \%$ GDP). Back in 2000, V. Tanzi and L. Schuknecht argued that in order to prevent public health problems along with increasing life expectancy, it was necessary to ensure a faster growth of spending on medical services compared to other budget services (Tanzi \& Schuknecht, 2000). Overall, budget expenditures on debt repayment and servicing in Ukraine will put constraints on budget funding of important social government functions for many years.

5. Budget receipts of corporate income tax will drop as a result of its rate cut not only in the short term but also in the long-run perspective. In the period of 2004-2008, corporate income tax was an important source of budget revenues: on the average it provided $14.1 \%$ of tax revenues of the general government (including tax revenues of the consolidated budget and contributions to the compulsory social security funds), while, in the period of 2014-2018, it collected only about $7 \%$. Shift in corporate income tax receipts from $4.9 \%$ GDP in the period of 2004-2008 down to $2.5 \%$ GDP in the period of 2014-2018 was induced by cutting the rate of corporate income tax from $25 \%$ in $2004-2008$ to $18 \%$ in $2014-2018$ in the absence of policy measures aimed at reducing the shadow economy and broadening the tax base.

6. Allocation of budget funds to cover pension payments. Compulsory social security contributions are not much sufficient to finance pension fund in Ukraine therefore it also requires government to add a large share of finance from the budget. For instance, in 2004, compulsory social security contributions made by employers could finance about $77 \%$ of the Ukrainian Pension Fund liabilities, but in the period of 2016-2018, when a unified contribution rate was cut down to $22 \%$, it could finance between 42 and 55\%. After the implementation of this reform, the Ukrainian Minister of Social Policy raised a question about a unified contribution rate increase, given the significant decline of its receipts. The Chairperson of the Verkhovna Rada Committee for Tax and Customs Policy of Ukraine also drew attention to the fact that business entities did not bring wages out of the shadows motivated by expectations of unpredictable and illogical changes in the government (Nina Yuzhanyna, 2016). In such conditions, a big amount of budget assignations on social protection and social welfare counts as subsidies to the Pension Fund of Ukraine. Thus, the reduction of the tax burden on corporate income in Ukraine by means of compulsory social security contributions should be preceded by consistent measures aimed at reducing the size of the shadow economy in Ukraine.

According to J. Stiglitz, through the use of globalization advantages, such as free movement of capital and assets, economic entities - under the imperfect corporate income tax system - are able to avoid paying taxes (Stiglitz, 2015). Such effects put tax collection at risk if the government does not tackle tax evasion in a timely manner. While the prevention of tax optimization risks, first and foremost, calls for strengthening of control over the effectiveness of tax incentives (by an independent control board) (Chapman \& Zahradnik, 2015), elimination of risks associated with changes in the behavior of economic entities requires the improvement of corporate income tax base formation and rescheduling its tax rates (Kopits, 2014). The government is responsible for creating such tax treatments so that the state can finance its commitments properly.

In Ukraine, the reduction of corporate income tax rates did not ensure the improvement of national tax competitiveness and investment growth. The main factors that hinder business activities and reduce the competitiveness of the national economy are as follows: corruption, judicial ineffectiveness, lack of reliable protection of property rights, restricted investment and financial freedom. The factors of economic freedom in Ukraine considering different variables (graded on a scale of 0 to 100) were estimated at no greater than 30 (protection of property rights -31.5 , see Table 2 ), which suggested an extremely insufficient rule of law guarantee as well as a lack of key prerequisites for free and effective business activity in Ukraine.

It should be kept in mind that the economy of Ukraine lists as a small, open, commodity model with a speculative grade rating. In 2018, Ukraine accounted for only $0.15 \%$ of world GDP with GDP per capita standing at $27.4 \%$ of the world average (The World Bank, 2018). This implies that Ukraine's economic decisions do not make any influence on the economies of developed countries.

Table 2

Key factors of the Index of Economic Freedom of Ukraine in 2004-2018

\begin{tabular}{|l|c|c|c|c|c|}
\hline & Property rights & Judicial effectiveness & $\begin{array}{c}\text { Government } \\
\text { integrity }\end{array}$ & Investment freedom & Financial freedom \\
\hline Average for 2014-2018 & 31.5 & 26.1 & 26.2 & 23.0 & 30.0 \\
\hline Average for 2004-2008 & 34.3 & 27.9 & 27.8 & 26.0 & 30.0 \\
\hline
\end{tabular}

Source: Authors' calculations based on the data from The Heritage Foundation (https://www.heritage.org/index/explore?view=by-region-country-year) 
Ukraine has an open economy - the volume of its foreign trade (based on the World Bank methodology) in 2018 was estimated at 99\% GDP, which is much higher than the world average (57.9\% GDP). Import of goods and services amounted to $53.8 \%$ GDP, which is $8.6 \%$ higher than exports, triggering the risk of exchange rate. Meanwhile, manufacturing equipment and vehicles accounted for almost $30 \%$ of import. At the same time, more than a half of export from Ukraine is led by raw materials (grain $15.3 \%$, oil seeds $4.1 \%$, mineral products $9.2 \%$ ), base metals and metal products $(24.6 \%)$, not by high-tech and innovative products with high added value.

Ukraine's economy still belongs to the category of economies with speculative grade ratings, although the international agency Fitch Ratings upgraded Ukraine to "B" from "B-" in September 2019 (Fitch Ratings, 2019). Despite this, such a situation has an adverse effect on the cost of borrowing by the government and companies. Moreover, it causes additional fiscal risks.

Small economies of various countries have common distinct features, which are different from those of "large" economies, that should be considered while carrying out their tax policy, namely: limited capacity to broaden economic base in the short and long-run term (due to inability to benefit from economies of scale, narrow specialization of production of goods for exports, significant vulnerability of the development of small economies to global shocks and unfavorable foreign market conditions, high economic instability); large public debt; small investments and savings (Lederman \& Lesniak, 2018).

Governments of small countries do not have enough flexibility to deal with risk situations (such as macroeconomic instability, unfavorable external market conditions, expansion of public social spending in the crisis period, high cost and limited access to external borrowing) and consequently to facilitate the development of fiscal space. In the countries with a high rate of corruption and the shadow economy, the risk forces become even more influential, which challenges against creating fiscal space in these countries. Our conclusion emerging out of the analysis and assessment of several tax reforms in Ukraine suggests that the stated goals of promoting the investment and reducing the shadow economy were not achieved.

Ukraine, as a country with a small, open, and mostly raw-oriented economy, with a high rate of corruption and undeclared incomes, is characterized by specific tax effects of cutting corporate income tax rates. Among those effects are, namely: drop of government revenues as a result of a tax rate cut as well as contribution cut not only in the short term but also in the longrun perspective; lack of measures of innovation and investment promotion; prevailing of outward investments over investments in the domestic economy of Ukraine. These effects should be considered when deciding on tax policy measures.

The key condition of the creating of good tax policy should provide long-term sustainability of public finances (Eichler \& Emmenegger, 2018), in other words to ensure such growth rate, when each generation is able to deal with their problems on their own account without shifting them on future generations, and take measures to prevent future problems (Deutsche Nachhaltigkeitsstrategie, 2016). In case of budget gap occurrence, measures of fiscal adjustment should be taken, for instance by increasing taxes provided that spending cut or public debt increase is impossible.

A fair intergenerational distribution of the tax burden can be achieved when current budget expenditures are financed by taxes and government borrowings are used only for investment. A fair intergenerational distribution of resources is a priority for the Australian government, which strives to ensure that future generations of taxpayers do not need to cope with an unmanageable account for public services provided to the current generation (Intergenerational Report, 2002).

Tax rates and other tax law provisions should be designed in a way to allow for the risk of rising public debt, reducing tax revenues (due to tax fraud) or increasing pressure on public spending.

The best practices of different countries which carry out anti-abuse tax policy show that when imposing corporate income tax and determining the appropriate tax base certain restrictions should be applied on the composition and amount of costs in the accounting system (Remeur, 2015; Coughlan, 2015; European Commission, 2016). It is known that the EU continues to struggle against corporate income tax evasion (understatement of the tax base, profit shifting, usage of offshore tax jurisdictions (offshore companies). Therefore, it is necessary for Ukraine to converge with the conditions of the EU countries on the procedure of tax base formation, reporting, information disclosure in financial and tax reporting as well as tax administration.

\section{Tax incentives instruments for the development of the national economy}

According to the approach of M. Porter, J.Sachs and J.McArthur, there are several stages in the economic development of countries: the first stage is determined by mobilization of primary factors of production, the second stage is mainly determined by the application of efficiency factors, the third is determined by innovation factors (Porter, Sachs \& McArthur, 2002). The transition from one stage to another (higher) stage requires promotion of the development factors and their additional funding. Today, Ukraine's economy is in the process of transition from the first stage of economic development to the second stage at the same time promoting innovation factors of economic 
development. It requires new principles of formation of investment resources of enterprises.

However, in Ukraine in the period of 2015-2018, on average, only $15.4 \%$ of enterprises introduced innovative technologies or new products (Scientific and innovative activity of Ukraine, 2019). The innovative development of Ukraine's economy should be ensured by a significant increase in corporate innovative investments, given that they are the main source of financing innovative activities (in different years they have accounted for between 85 and $97 \%$ of total innovation costs). It is a shortage of own funds or insufficient government support that hamper the creation of innovations by corporate sector (Survey of innovation, 2017).

Considering that in the environment of increasing global competition, economic development depends not only on available factors of production but, first and foremost, it is determined by innovative factors, the efficiency of their usage, successful economic development of Ukraine requires higher funding of innovative and investment activities by introducing, for example, targeted innovation tax incentives on corporate income. The policy-making decisions on application of innovation tax incentives in Ukraine require a reliable methodological approach of their impact evaluation on both government budget (which loses the subsequent tax revenues) and on enterprises (which thus receive additional financial resources by reducing taxation).

To solve these problems, a toolkit for forecasting the effect of tax incentives on innovation development of enterprises in the short and medium term and for the choice of proper innovation tax relief provisions (tax credit or enhanced deductions of $\mathrm{R} \& \mathrm{D}$ costs from the corporate income tax base) (Lunina \& Bilousova, 2018). We believe that innovation tax incentives have a strong impact on the development of fiscal space in the medium and long term.

\section{Conclusions}

The tax system of Ukraine (as well as of other countries with a small, open economy and with a high rate of corruption and shadow economy) should be tailored within a concept of sustainable development in a way that allows for the effects of government decisions on the current and long-term budgets, which involves the interest of future generations. Much attention needs to be drawn to the dynamics of public debt and the cost of its servicing, to the options that would increase tax revenues such as reduction of corruption and unreported income in order to finance productive budget spending and capital investment, to the measures of innovation promotion as an important driver for economic development.

The reduction of government expenditures should proceed within the wide program ofeconomicreforms that will ensure more efficient use of resources. Underfunding of government functions can deteriorate the conditions for economic growth and human capital development (if education and health care is underfunded), and, therefore, negatively affect the development of national economy and fiscal space in the future.

Carrying out tax reforms and expanding fiscal space in transition economies requires:

- considering the specific effects of changing corporate income tax provisions, namely, the impact of cutting tax rates on the level of tax revenues in the medium and long term, on innovation and investment activities, on the dynamics of investment flows beyond the borders of the country, on the reduction of the size of the shadow economy, etc.;

- ensuring the long-term sustainability of public finances, including the prevention of shifting of existing fiscal problems on future generations and induction of fair intergenerational distribution of the tax burden (current budget expenditures are financed by taxes and government borrowings are only used for capital investments);

- imposing certain restrictions on the kinds and volume of enterprises' costs, which are accounted for the corporate income tax base; improving tax administration and tax control to overcome tax evasion;

- a reorientation of the government tax support (by providing targeted innovative corporate income tax incentives) on projects that in the medium term can spur innovations, increase the technology level of production, improve labor productivity and gain higher competitiveness of the country in the world markets, facilitate the growth of the country's future revenue receipts.

\section{References:}

Blankart, Ch. B. (2000). Derzhavni finansy v umovakh demokratii. Vstup do finansovoi nauky [Public finances in a democracy. Introduction to Financial Science]. Kyiv: Lybid.

Braid, R. M. (1993). Spatial competition between jurisdictions which tax perfectly competitive retail (or production) centers. Journal of Urban Economics, vol. 34(1), pp. 75-95.

Braid, R. M. (2005). Tax competition, tax exporting and higher-government choice of tax instruments for local governments. Journal of Public Economics, vol. 85, pp. 1789-1821. doi: 10.1016/j.jpubeco.2004.04.004

Brys, B., Matthews, S., \& Owens, J. (2011). Tax Reform Trends in OECD Countries. Taxation Working Papers, vol. 1. doi: $10.1787 / 5 \mathrm{~kg} 3 \mathrm{~h} 0 \mathrm{xxmz} 8 \mathrm{t}$-en

Bunn, D., \& Asen, E. (2019). International tax Competitiveness Index 2019. Tax Foundation, p. 63. Retrieved from: https://files.taxfoundation.org/20190930115625/2019-International-Tax-Competitiveness-Index.pdf 
Chapman, J., \& Zahradnik, R. (2015). Reducing Budget Risks. Report «Economic Development Tax Incentives, States' Fiscal Health». Retrieved from: https://www.pewtrusts.org/en/research-and-analysis/reports/2015/12/ reducing-budget-risks

Coughlan, V. (2015). Europe's Push For Tax Transparency Picks Up The Pace. Law360, New York. Retrieved from: https://www.cov.com/ /media/files/corporate/publications/2015/12/europe_push_for_tax_transparency_ picks up the pace.pdf

Dehejia, V. H., \& Genshel, Ph. (1998). Tax Competition in the European Union. MPIfG Discussion Paper, № 98/3. Retrieved from: www.europarl.europa.eu/workingpapers/econ/pdf/105_en.pdf

Deutsche Nachhaltigkeitsstrategie. Neuauflage 2016,. Retrieved from: https://www.bundesregierung.de/ resource/blob/975292/730844/3d30c6c2875a9a08d364620ab7916af6/deutsche-nachhaltigkeitsstrategieneuauflage-2016-download-bpa-data.pdf?download=1

Eichler, M., \& Emmenegger, M. (2018). Low taxes and spending discipline: Swiss public finances healthy. Retrieved from: http://www.baktaxation.com/media/BakDownloadStucktur/Medienmitteilungen/2018/2018 12_27_Low_taxes_and_spending_discipline_Swiss_public_finances_healthy.pdf

Employer social security tax rates. (2019). Retrieved from: https://home.kpmg/xx/en/home/services/tax/taxtools-and-resources/tax-rates-online/social-security-employer-tax-rates-table.html (accessed May 28, 2020).

European Commission (2016). Commission proposes major corporate tax reform for the EU. Retrieved from: https://ec.europa.eu/commission/presscorner/detail/en/IP_16_3471 (accessed May 28, 2020).

Fitch Ratings. Ukraine. (2019). Retrieved from: https://www.fitchratings.com/search?\&query=ukraine\&date Value=lastYear (accessed May 28, 2020).

Fuest, C. (2019). Steuerreform statt zusätzliche Staatsausgaben. IFO Standpunkte, vol. 203. Retrieved from: https://www.ifo.de/Standpunkt/ifo-Standpunkt-203-Steuerreform-statt-zusaetzliche-Staatsausgaben

Gordon, R. H., \& Bovenberg, A. L. (1994). Why is capital so immobile internationally? Possible explanations and implications for capital income taxation. NBER Working Paper, vol. 4796, p. 33. Retrieved from: www.nber.org

Index of Economic Freedom. 2020. Retrieved from: https://www.heritage.org/index/explore?view=by-regioncountry-year (accessed May 28, 2020).

Intergenerational Report 2002-03. Commonwealth of Australia. The Treasury, Parkes ACT. Budget Paper, vol. 5. Retrieved from: www.treasury.gov.au

Johansson Å., Heady C., Arnold J., Brys B., \& Vartia L. (2008). Taxation and Economic Growth. OECD. Economics department. Working Paper, vol. 620. doi: 10.1787/18151973

Kazutoshi, M., Hikaru, O., \& Toshiki, T. (2018). Tax Competition and Fiscal Sustainability. Retrieved from: http://www.cirje.e.u-tokyo.ac.jp/research/dp/2018/2018cf1103.pdf

Kopits, G. (2014). Coping with fiscal risk. Analysis and practice. OECD Journal on Budgeting, vol. 14, no. 3, pp. 47-71. doi: $10.1787 / 16812336$

Lederman, D., \& Lesniak, J.T. (2018). Open and Nimble Finding Stable Growth in Small Economies International Bank for Reconstruction and Development. The World Bank. doi: 10.1596/978-1-4648-1042-8

Lunina, I. O., \& Bilousova, O. S. (2018). Instrumentarij prohnozuvannia biudzhetnykh naslidkiv podatkovoho stymuliuvannia innovatsijnoi diial'nosti [Tools for forecasting the budgetary consequences of tax incentives for innovation]. Statistics of Ukraine, no. 2, pp. 51-61. doi: 10.31767/su.2(81)2018.02.07

Naukova ta innovatsijna diial'nist' Ukrainy. 2019 [Scientific and innovative activity of Ukraine. 2019]. State Statistics Service of Ukraine. Statistical Collection.

Nyna Yuzhanyna o ESV: Vremeny u nas net [Nina Yuzhanina on ERUs: We don't have time]. April 5, 2016. Retrieved from: https://dengi.ua/magazine/nedvizhimost/1795699-nina-juzhanina-o-esv-vremeni-u-nas-net

Obstezhennia innovatsijnoi diial'nosti v ekonomitsi Ukrainy za period 2014-2016 rokiv (za mizhnarodnoiu metodolohiieiu) (2017) [Survey of innovation activity in the economy of Ukraine for the period 20142016 (according to the international methodology)]. State Statistics Service of Ukraine. Retrieved from: http://www.ukrstat.gov.ua

Overesch, M., \& Rincke, J. (2011). What Drives Corporate Tax Rates Down? A Reassessment of Globalization, Tax Competition, and Dynamic Adjustment to Shocks. The Scandinavian Journal of Economics, vol. 113, issue 3, pp. 579-602.

Porter, M., Sachs, J., \& McArthur, J. (2002). Executive summary: Competitiveness and stages of economic development. The global competitiveness report 2001-2002. New York: Oxford University Press. Retrieved from: http:/ / citeseerx.ist.psu.edu/viewdoc/download?doi=10.1.1.476.4940\&rep=rep1\&type=pdf

Porter, M. E. (2007). Konkurentsyia [Competition]. Moscow: Williams. Retrieved from: www.williamspublishing.com Remeur, C. (2015). Tax policy in the EU. Taxation. In depth analysis. European Parliamentary Research Service. Members' Research Service. PE549.001. doi:10.2778/541941

Rozen, H. (1992). Public finance. [3rd ed.]. USA: IRWIN Inc.

Schneider, F., \& Boockmann, B. (2020). Die Größe der Schattenwirtschaft - Methodik und Berechnungen für das Jahr 2020. Linz und Tübingen.

Smith, A. (1935). Yssledovanye o pryrode y prychynakh bohatstva narodov [A study on the nature and causes of the wealth of peoples]. Moscow. 
Stiglitz, J. (2015). Tax avoidance fuels global inequality. Retrieved from: http://edition.cnn.com/2015/10/09/ opinions/stiglitz-tax-avoidance-globalization/

Tanzi, V. (2007). Fiscal Policy in the Future: Challenges and Opportunities. "Fiscal Policy Challenges in Europe", Berlin, March 22-23, 2007. Retrieved from: https://pdfs.semanticscholar.org/f240/e74022a1e 03969a9a2799797b4603e5e0f66.pdf

Tanzi, V. (2014). Taxation and Equitable Economic Development. A Historical Note, November 2014.

Tanzi, V., \& Schuknecht, L. (2000). Public spending in the 20th Century: a global perspective. Cambridge University Press.

The World Bank (2018). GDP per capita. World Bank national accounts data, \& OECD National Accounts data files. Retrieved from: https://data.worldbank.org/indicator/NY.GDP.PCAP.CD?locations=UA (accessed May 28, 2020).

World Investment Report 2013: Global ii Value Chains: Investment and Trade for Development [coordin. by James Zhan]. Geneva: UNCTAD, United Nations Publication, 236 p. Retrieved from: https://unctad.org/en/ PublicationsLibrary/wir2013_en.pdf (accessed May 28, 2020).

Zahalni tendentsii tinovoi ekonomiky v Ukraini u 2018 rotsi. Ministerstvo ekonomichnoho rozvytku Ukrainy [General trends of the shadow economy in Ukraine in 2018]. Ministry for Development of Economy, Trade and Agriculture of Ukraine. Retrieved from: https://www.me.gov.ua/Documents/List?lang=uk-UA\&id=e384c5a76533-4ab6-b56f-50e5243eb15a\&tag=TendentsiiTinovoiEkonomiki (accessed May 28, 2020). 